\title{
Are there differences in practising and motivation between beginners playing different musical instruments?
}

\section{Existem diferenças na prática e na motivação entre alunos iniciantes tocando diferentes instrumentos musicais?}

\author{
Susan Hallam * \\ UCL Institute of Education, University College London, London, UK \\ s.hallam@ucl.ac.uk \\ Andrea Creech ** \\ Faculty of Music, Université Laval, Québec City, Canada \\ andrea.creech@mus.ulaval.ca \\ Maria Varvarigou ${ }^{* * *}$ \\ Canterbury Christ Church University, Canterbury, UK \\ maria.varvarigou@canterbury.ac.uk
}

* Susan Hallam is Emerita Professor of Education and Music Psychology at the UCL Institute of Education. She pursued careers as a professional musician and a music educator prior to becoming an academic in 1991. Her research has focused on issues relating to learning and the wider benefits of music.

** Andrea Creech is Professor of Didactique Instrumentale at Université Laval, where she holds a Canada Research Chair in music in community. Following an international orchestral and teaching career Andrea was awarded a PhD in Psychology in Education from the Institute of Education, University of London. Andrea has presented at international conferences and published widely on topics concerned with and lifelong learning and participation in music.

*** Maria Varvarigou is a Senior Lecturer in Music at Canterbury Christ Church University.Her special areas of interest include music and wellbeing; ear-playing and performance practices of vernacular music; effective teaching and learning in higher and professional education, intergenerational music-making; and choral conducting education. 


\section{Resumo}

Há um número considerável de pesquisas sobre a prática instrumental e a motivação musical. Este trabalho teve como objetivo ampliar a pesquisa nesta temática investigando as relações quanto à prática e à motivação de alunos iniciantes de diferentes instrumentos. Aproximadamente 500 instrumentistas e cantores de nível elementar responderam a um questionário com tópicos variados focalizando o tempo gasto praticando o instrumento, as estratégias da prática instrumental (ou vocal), a organização da prática, a motivação para a prática, o apoio recebido para tocar um instrumento, as autocrenças, a identidade musical, o prazer da performance e as aspirações musicais. Os participantes, que foram divididos em sete grupos instrumentais (cordas, sopro, metais, piano/instrumentos de teclado, violão, bateria e voz), responderam ao questionário em uma escala Likert de sete pontos. A análise multivariada foi realizada em relação ao tempo gasto praticando, às estratégias de prática e às atitudes frente à prática e à motivação. As análises consideraram o grupo instrumental, a idade e o gênero, mostrando a complexa relação entre eles. Os resultados são discutidos em termos de suas implicações para o ensino.

Palavras-chave: Música. Prática. Motivação. Instrumentos. Idade. Gênero.

\section{Abstract}

There has been considerable research on instrumental practice and musical motivation. This paper aimed to extend this research studying instrument differences in beginner players in relation to their practice and motivation. Almost 500 beginner instrumentalists and vocalists completed a questionnaire which consisted of a number of statements relating to time spent practicing, practicing strategies, organisation of practice, motivation to practice, support for playing an instrument, self-beliefs, musical identity, enjoyment of performance and musical aspirations. Participants, who were divided into seven instrumental groups (strings, woodwind, brass, piano/keyboard, guitar, drummers, and voice) responded on a seven-point Likert scale. Multivariate analysis was undertaken in relation to time spent practicing, practice strategies, attitudes towards practice and motivation. The analyses took account of instrument group, age and gender and showed the complexity of the relationships between these. The findings are discussed in terms of their implications for teaching.

Keywords: Music. Practice. Motivation. Instruments. Age. Gender. 


\section{Introduction}

Research on instrumental music practice has tended to focus on two main issues: time spent practicing and its impact on the level and quality of musical outcomes; and the quality of practice and how to improve it (for a recent review see JØRGENSEN; HALLAM, 2016). Similarly, research on motivation has considered what factors contribute to engaging with and continuing to play a musical instrument and what might lead to dropout (for a review see HALLAM; BURNS, 2018). A gap in the research has been whether there are instrument differences in practice and motivation. Such research as has been undertaken has tended to be undertaken with samples of musicians with relatively high levels of expertise and the findings have been interpreted in terms of the differing demands of each instrument technically and in terms of its repertoire. This has meant that information which may help teachers support beginners, who may differ in age, gender and the instrument that they play has not been available. This research addresses this issue by analysing beginner instrumentalists' and vocalists' responses to statements on a questionnaire using a seven-point Likert scale. The statements were derived from previous research discussed below. Those related to practice focused on areas identified in previous research which were related to the extent to which practice was effective including the strategies that learners adopt, the way that they organize practice, the extent to which they are able to concentrate and their attitudes towards practice (for a recent review see JØRGENSEN; HALLAM, 2016). Research on motivation to continue playing an instrument has repeatedly shown its complexity and a range of models have been developed which outline the various factors which contribute (for a recent review see HALLAM, 2016). These include the extent to which the individual receives support for playing an instrument, their musical social life, their self-beliefs about their musical potential, their enjoyment of performance and musical activities, and their musical aspirations (see HALLAM, 2013).

Historically, much research has been undertaken exploring changes in practice as expertise develops (GRUSON, 1988; HALLAM, 1997; HALLAM et al., 2012; MCPHERSON; RENWICK, 2001; PITTS et al., 2000a). Taken together, the existing research has shown that as young people develop their musical expertise there is an increase in the identification of difficult sections and repetition of these, while errors, time wasting and repeating single notes decreases. Only when students have considerable expertise and well developed aural schemata are errors consistently corrected. Some research has focused on the organisation of practice and its impact on effectiveness (e.g. PRICE, 1992; BARRY, 1992), while other studies have concentrated on the extent to which musicians carry out warm up exercises (e.g. HALLAM, 1995; JØRGENSEN, 1998) or complete technical work before practicing repertoire (DUKE et al., 1997; SLOBODA et al. 1996). Having well-defined aims for practice may support concentration (ERICSSON et al., 1993) but beginners and even more accomplished students often fail to formulate goals for practice activities and mastering specific tasks (JØRGENSEN, 1998).

In a very large-scale study, (HALLAM et al., 2012) explored changes in strategy use and found that as expertise developed learners were better at recognising errors, and 
were more likely to adopt effective practice strategies, including identifying difficult passages, practicing them slowly, and gradually speeding up. They were less likely to adopt ineffective strategies, typically playing through the piece without stopping. There was also greater use of the metronome and self-recordings to support ongoing improvement and recordings of others to learn the sounds of pieces to be learned. There were no differences in perceived concentration, organisation of practice or the use of non-playing analytic strategies as expertise developed.

Research on instrument differences in practice is relatively rare. Jørgensen (1997, 2002) studied differences in time spent practicing in conservatoire students. He collected data from a population of 182 students enrolled in one of four programmes: instrumental, vocal, church music or music education. The questionnaire differentiated between solitary practice and practice with others. Eighty five percent of the students reported practicing on 6 or 7 days each week and there was a mean daily practice time of 2 hours 40 minutes. The pianists practiced the most doing about 32 hours 45 minutes practice each week followed by the string players who did on average 28 hours 10 minutes each week. The brass and woodwind players did considerably less practice, 18 hours 50 minutes and 18 hours 10 minutes respectively. However, there was wide variation, for instance, amongst the brass players time spent practicing varied from 570 minutes to 1131 , for the pianists from 450 to 1323 minutes, for the strings from 840 to 1690 minutes and for the woodwind 420 to 1088 minutes. There were also differences within each group, for instance, in the string group it was the violinists who did the most practice, in the woodwind the oboists and in the brass, the tuba players. This study was replicated by Lammers and Kruger (2006) with American and Japanese students playing brass and woodwind instruments. The findings were similar with the brass students reporting carrying out 948 minutes practice each week in the USA and 1264 in Japan. The woodwind students reported 775 minutes practice in the USA and 783 in Japan. The findings from this research have been interpreted in terms of the physical and technical demands of the instrument and the nature and extent of the repertoire. The research reported here extends this work to consider differences in beginner instrumental and vocal students, not only in the time spent practicing but also the kinds of practice strategies adopted.

Existing research on motivation to play a musical instrument has had implications for understanding how and why beginner instrumentalists engage with practice. A range of motivation models have emerged which recognise the interactions which occur between environmental (cultural, institutional, familial and educational) and internal factors (cognition and affect) which enhance or reduce motivation (see ASMUS 1994; AUSTIN; RENWICK; MCPHERSON, 2006; EVANS; MCPHERSON; DAVIDSON, 2013; HALLAM, 2002; 2016; O'NEILL; MCPHERSON, 2002; SICHIVITSA, 2007). Four main motivational themes have emerged from previous research: satisfying personal needs; developing and maintaining a positive musical identity; acquiring effective approaches to learning music; and having a supportive environment. The balance between these motives changes over time as individuals progress through their musical careers (see HALLAM et al., 2016). In the early years of playing relatively uncritical support from 
teachers, families and others is important (HARNISCHMACHER, 1997; MANTURZEWSKA, 1990; SOSNIAK, 1985).

Social interactions play an important role in students' motivation to engage in active music making (CREECH; HALLAM, 2003; CREECH, 2008; DAVIDSON et al., 1996). The support of family, friends and colleagues is particularly important (AUSTIN; VISPOEL, 1998; BURLAND; DAVIDSON, 2002; CREECH, 2009; CREECH; HALLAM, 2011; DAVIDSON et al, 1996; HOWE; SLOBODA, 1991; LEGETTE, 2003; MACNAMARA et al., 2006; MOORE; BURLAND; DAVIDSON, 2002; PATRICK et al., 1999; ZDZINSKI, 2013). Families who have musical skills and are interested in music seem to be able to transfer these values and interests to their children (MOORE et al., 2003; PITTS et al., 2000a; ZDINSKI, 1996). Where parents are indifferent or less involved, children are more likely to give up playing (DAVIDSON et al., 1996; O'NEILL, 2002; PITTS et al., 2000a).

Teachers are also crucial in motivating learners (ASMUS, 1989; CREECH; HALLAM, 2011; DAVIDSON et al., 1996; 1998; DUKE; FLOWERS; WOLFE, 1997; LAMONT 2002; SLOBODA; HOWE 1991; SOSNIAK 1985; SZUBERTOWSKA, 2005) and act as important role models (MANTURZEWSKA, 1990). How pupils and teachers relate to each other has an impact on learners' love of music (BAKKER, 2005; CASSIE, 2008; STGEORGE, 2010). Pupils who give up playing have poorer relationships with their teachers than their peers (STGEORGE, 2010). They also tend to engage in more teacher approval seeking behaviour (COSTA-GIOMI; FLOWERS; SASAKE, 2005; MCPHERSON; RENWICK, 2001). For some, participation in ensembles or the opinions of their parents and friends are crucial in shaping their own attitudes towards music (PITTS et al., 2000a; 200b). For long-term commitment to making music, motivation needs to be intrinsic.

There are considerable differences in the level of commitment that individuals make to music. For many children who begin to play an instrument, this activity is viewed no differently from other activities which they undertake in their free time (MCPHERSON; MCCORMICK, 2000). In contrast, some make an early commitment and demonstrate dedication, determination and a willingness to make sacrifices (MACNAMARA et al., 2006). Indeed, Kemp (1996) found that the most accomplished classical musicians in his sample were self-motivated almost to the point of obsession.

The research reported here explores issues relating to practice and motivation in beginner instrumentalists and vocalists, taking account of gender and age, with particular reference to the differences between: strings, woodwind, brass, drummers, guitar, piano/keyboard and vocalists.

The specific research questions were:

Are there differences between those in different instrument groups in:

- the amount of practice undertaken;

- the practice strategies adopted;

- attitudes towards practice;

- social support for playing an instrument;

- participation in musical social activities;

- self-beliefs;

- enjoyment of performance;

- overall attitudes towards playing an instrument? 


\section{Methods}

The study's questionnaire was devised based on the research literature and a prior study (HALLAM, 2013). Respondents were asked to indicate the length of time they had spent learning to play an instrument and the number and length of practice sessions in a typical week. The questionnaire also included a range of statements relating to: the practicing strategies adopted; the organization and management of practice; motivation to practice; support for playing an instrument; musical social activities; self-beliefs; enjoyment of performance; musical aspirations; and enjoyment of musical activities. Respondents were requested to respond to these on a seven-point Likert scale with seven indicating the strongest agreement, one the strongest disagreement. The questionnaire was piloted on a small group of young musicians to ensure that the statements were easy to understand. Their feedback indicated that no changes were required. The full questionnaire is included in the appendix.

\section{Respondents}

The research was undertaken in England and was part of a larger study of practice and motivation including over 3,000 children and young people with a range of expertise from beginner to graded examination level 8 . The participants were receiving instrumental or vocal tuition individually or in small groups of no more than four children and were representative of children learning to play instruments within the English education system. The organisations which the children were attending, local music centres, junior conservatoires or schools, were approached and permission requested for questionnaires to be administered. Convenient times for the researchers to visit the organisations were negotiated. The analysis reported here focuses on the 488 instrumental learners of the sample who were at the lowest level of expertise and had not yet taken their first graded instrumental examination. 161 of the sample were male, 264 were female. The students were divided into 3 age groups broadly based on the phases of schooling in England. There were 171 between 7-10 years, 170 between 11 and 14 years and 81 who were 15 years or older.

The young people were grouped into instrumental groups. In some cases, this was a simple process as they were the traditional orchestral groups, for instance, strings, woodwind, brass. In other cases, particularly where there were very small numbers playing a particular instrument they were placed in a group where there were some similarities, e.g. percussion players were placed in a group headed drummers. All guitars are included in one group. Classical guitar dominated in this group although some learners were playing electric or bass guitar. However, these were in the minority. Table 1 sets out the details of the sample. 


\begin{tabular}{|l|c|c|c|c|c|c|c|}
\hline & Frequency & Percentage & Male & Female & Age 7-10 & Age 11-14 & Age 15+ \\
\hline Piano, keyboard & 76 & 15.6 & 39 & 32 & 14 & 40 & 20 \\
\hline Woodwind & 112 & 23.0 & 23 & 84 & 73 & 25 & 14 \\
\hline Brass & 23 & 4.7 & 14 & 8 & 8 & 9 & 6 \\
\hline Strings & 159 & 32.6 & 43 & 113 & 86 & 59 & 10 \\
\hline Voice & 24 & 4.9 & 2 & 22 & 1 & 11 & 12 \\
\hline Guitar (all) & 75 & 15.4 & 46 & 28 & 25 & 30 & 18 \\
\hline Drums & 19 & 3.9 & 14 & 4 & 7 & 8 & 4 \\
\hline Total & 488 & $100 \%$ & 181 & 291 & 214 & 182 & 84 \\
\hline
\end{tabular}

Not all respondents indicated their gender or age

Table 1: The sample

\section{Procedure}

The research was designed taking account of the ethical guidelines of the British Psychological Society and the British Educational Research Association and was approved by the ethics committee of the Institute of Education, University of London. The organisations that the young people were attending were contacted and asked if they would be willing for the researchers to collect data from students. The young people themselves were told that they did not have to participate if they did not wish to do so and were assured that the data would remain confidential and that their parents and teachers would not have access to it. Informed consent from the young people was obtained as part of the questionnaire process. Parents were informed that the research was taking place and given the opportunity to withdraw their children from the research.

The researchers administered the questionnaires to students in the various learning environments. The exact procedures for this varied depending on the environment. For instance, in schools, the children completed the questionnaires during music lessons, while in the extra-curricular environments questionnaires were distributed and collected during break periods between musical activities.

\section{Analysis of the data}

Multivariate analysis of variance (MANOVA) was adopted to analyse the data where the underlying assumptions were met. MANOVA involves analysis of more than one variable at a time. The advantage of using multivariate analysis of variance is that when there are a large number of variables, as in this case, it reduces the possibility of inflated Type 1 error due to multiple test of correlated dependent variables. Levene's test of homogeneity of variance showed that there were no significant differences in homogeneity of variance for most of the variables with the exception of the amount of practice undertaken each day. Because of this, the variables relating to time spent practicing were therefore analysed using univariate analyses of variance. Three multivariate analyse were undertaken focusing on: practicing strategies; attitudes towards practice; and motivation. The analysis took account of instrument group, age and gender simultaneously. 


\section{Time spent practicing}

Instrument group: The univariate analysis of the data relating to time spent practicing showed that there was no statistically significant difference between the instrument groups in relation to the average number of days practiced each week. Typically, the beginners practiced for 4.3 days each week. There was a statistically significant difference in the average daily practice between instruments $(F(6)=2.6, p=.017)$. The guitar players reported doing the most practice, 45.2 minutes daily followed closely by the pianists who undertook 41.5 minutes daily. Those practicing the least each day were the woodwind players ( 22.1 minutes) followed by the singers ( 26.8 minutes). Overall, learners reported practicing for an average of 32.6 minutes each day. The average number of months learning was 29.8. There were statistically significant instrument differences in length of months learning $(F(6)=6.21, p=.0001)$. The singers had been learning for the longest period of time (34.9 months) and the woodwind players the shortest (21.8 months) (see Table 2).

Age: The univariate analysis revealed statistically significant differences in terms of age in relation to time spent practicing. There were statistically significant differences in relation to each element in terms of age. The average number of days practiced increased with age $(F(3)=3.91, p=.009)$, as did the amount of time spent practicing $(F(3)=8.67$, $p=.0001)$ and the length of time spent learning $(F(3)=26.74, p=.0001)$ (see Table 3 ). There was a statistically significant interaction between instrument group and age in relation to the number of days practiced $(\mathrm{F}(12)=2.15, \mathrm{p}=.013)$.

Table 4 sets out the relationships between instrument group and age. There were different patterns for the different instruments in terms of the number of days practiced, although for practice time in each session and the length of time spent learning, the time increased for all instruments with age. Overall, there were clear instrument differences, although these were mediated by age.

Gender: The univariate analysis revealed no statistically significant differences in terms of gender or any statistically significant interaction between instrument group, age and gender, although there were statistically significant interactions between gender and age relating to the number of days when practice was undertaken $(F(2)=3.5, p=$ .031) and the time spent practicing each day $(F(2)-4.09, p=.017)$.

\begin{tabular}{|l|c|c|c|}
\hline $\mathrm{N}=468$ & $\begin{array}{c}\text { Average days each week } \\
\text { when practice occurs }\end{array}$ & Average daily practice & Number of months learning \\
\hline Piano, keyboard & 4.4 & 41.5 & 29.3 \\
\hline Woodwind & 4.2 & 22.1 & 21.8 \\
\hline Brass & 3.8 & 35.3 & 27.2 \\
\hline Strings & 4.5 & 30.6 & 33.1 \\
\hline Voice & 4.2 & 26.8 & 34.9 \\
\hline Guitar (all) & 4.3 & 45.2 & 33.1 \\
\hline Drums & 3.5 & 28.7 & 33.7 \\
\hline Total & 4.3 & 32.6 & 29.8 \\
\hline
\end{tabular}

Table 2: Time spent practising by instrument group 


\begin{tabular}{|l|c|c|c|c|c|}
\hline $\mathrm{N}=468$ & $7-10$ years & $11-14$ years & $15+$ years & Total & Sig \\
\hline $\begin{array}{l}\text { Average days practised } \\
\text { each week }\end{array}$ & $4.1(1.9)$ & $4.2(2.0)$ & $4.4(1.9)$ & $4.2(1.9)$ & .006 \\
\hline Average daily practice & $20.2(19.7)$ & $36.6(36.0)$ & $53.5(42.5)$ & $32.3(33.6)$ & .0001 \\
\hline Number of months learning & $16.9(13.2)$ & $31.1(27.9)$ & $53.5(40.2)$ & $28.7(28.7)$ & .0001 \\
\hline
\end{tabular}

Standard deviations are indicated in the bracketed figures

Table 3: Time spent practising by age

\begin{tabular}{|l|c|c|c|c|c|c|c|c|c|}
\hline & \multicolumn{3}{|c|}{$\begin{array}{l}\text { N }=468 \\
\text { week }\end{array}$} & \multicolumn{3}{|c|}{ Average daily practice } & \multicolumn{3}{c|}{ Number of months learning } \\
\hline & Age 7-10 & Age 11-14 & Age 15+ & Age 7-10 & Age 11-14 & Age 15+ & Age 7-10 & Age 11-14 & Age 15+ \\
\hline $\begin{array}{l}\text { Piano, } \\
\text { keyboard }\end{array}$ & 4.1 & 4.4 & 4.6 & 16.5 & 41.6 & 55.5 & 22.1 & 23.0 & 43.5 \\
\hline Woodwind & 4.2 & 4.1 & 3.9 & 20.6 & 20.5 & 32.8 & 14.4 & 28.3 & 48.9 \\
\hline Brass & 5.0 & 3.2 & 3.2 & 15.6 & 43.3 & 49.3 & 18.3 & 19.7 & 50.5 \\
\hline Strings & 4.3 & 4.6 & 4.9 & 19.5 & 42.2 & 71.8 & 17.7 & 46.5 & 85.0 \\
\hline Voice & 0 & 4.8 & 4.0 & 0 & 13.6 & 41.3 & 00 & 32.1 & 40.4 \\
\hline Guitar (all) & 3.8 & 4.0 & 5.2 & 29.3 & 40.3 & 70.0 & 20 & 21.7 & 54.5 \\
\hline Drums & 2.0 & 4.4 & 4.5 & 8.6 & 36.3 & 48.8 & 12.3 & 30.3 & 78.0 \\
\hline
\end{tabular}

Table 4: Time spent practising by instrument group and age

\section{Practice Strategies}

Instrument group: The multivariate analysis revealed a statistically significant impact of instrument group on practicing strategies $(F(162,2190)=1.2, p=.36)$.

There were few statistically significant differences in relation to individual statements between those playing different instruments in relation to the practicing strategies adopted. In relation to the organisation of practice, across all instruments there was a lack of strong agreement that targets were set for practice sessions $(M=4.2)$ or that a list was made of what had to be practiced $(M=3.4)$. Overall, practice tended not to be begun with studies (3.5) or scales (3.6), although more young people did undertake warm ups (4.5). The exception to this was the singers who reported much more strongly than any other group that they did warm up exercises $(M=5.6)$. This difference was statistically significant (see Table 5).

The beginners, overall, reported that they tried to get an overall idea of a piece before practicing it $(M=4.9)$ and that they thought about how they wanted the music to sound $(M=4.6)$. There was less support for marking things on the part to help them ( $M$ = 3.9), analysing the structure of the work before playing $(M=4.0)$, and working things out just by looking at the music $(M=3.8)$. There were statistically significant differences in trying to find out what a piece sounded like before playing $(p=.032)$. Most likely to do this were the singers $(M=5.3)$ and drummers $(M=5.3)$, least likely the string players $(M=4.5)$ (see Table 5). There were no statistically significant differences in relation to reported concentration. Overall, respondents reported that they found it reasonably easy to concentrate $(M=5.2)$ and were not easily distracted $(M=3.9)$ (see Table 5). 
There were no statistically significant differences between the groups in the perceived effectiveness of their practice. There was general agreement that they knew when they had made a mistake $(M=5.6)$. The most commonly adopted practicing strategy was playing something over and over again $(M=5.6)$ followed by 'when I make a mistake I practice the section where I went wrong slowly' $(M=5.3)$. There were similar overall means for practicing things slowly $(M=4.9)$; playing slowly to start with and then speeding up $(M=5.0)$; working out where there were difficult sections $(M=5.0)$; and practicing small sections $(M=4.8)$.

There were no statistically significant differences in relation to the adoption of ineffective practice strategies. The most common of these was when making a mistake, stopping, correcting the wrong note, and carrying on $(M=4.9)$. Less common were going back to the beginning after making a mistake $(M=4.0)$, practicing from beginning to end without stopping (3.6), and carrying on when having made a mistake without correcting it $(M=3.6)$.

There were no statistically significant differences in relation to practicing with a metronome $(M=3.0)$, recording oneself playing and listening to the tapes $(M=2.8)$ or listening to recordings of the piece to be learned $(M=3.7)$. All of these strategies were relatively uncommon.

\begin{tabular}{|c|c|c|c|c|c|c|c|c|c|}
\hline Statement & Age 7-10 & Age 11-14 & Age 15+ & Age 7-10 & Age 11-14 & Age 15+ & Age 7-10 & Age 11-14 & Age 15+ \\
\hline \multicolumn{10}{|l|}{ Organisation } \\
\hline $\begin{array}{l}\text { I set myself targets } \\
\text { to achieve in each } \\
\text { practice session }\end{array}$ & $4.0(1.5)$ & $4.3(1.7)$ & $4.1(1.3)$ & $4.3(1.7)$ & $4.8(1.7)$ & $3.9(1.9)$ & $4.0(2.0)$ & $4.2(1.7)$ & NS \\
\hline $\begin{array}{l}\text { I make a list of what } \\
\text { I have to practise }\end{array}$ & $3.4(1.9)$ & $3.6(2.1)$ & $3.8(1.2)$ & $3.6(1.9)$ & $2.7(1.2)$ & $3.0(1.7)$ & $2.6(1.5)$ & $3.4(1.9)$ & NS \\
\hline $\begin{array}{l}\text { I start my practice } \\
\text { with studies }\end{array}$ & $3.5(1.6)$ & $3.3(1.8)$ & $4.0(1.3)$ & $3.6(1.8)$ & $3.5(1.7)$ & $3.5(1.7)$ & $2.8(1.7)$ & $3.5(1.7)$ & NS \\
\hline $\begin{array}{l}\text { I start my practice } \\
\text { with scales }\end{array}$ & $3.4(1.7)$ & $3.8(2.1)$ & $3.7(1.3)$ & $3.7(1.7)$ & $4.3(2.0)$ & $3.3(1.9)$ & $3.5(2.3)$ & $3.6(1.9)$ & NS \\
\hline $\begin{array}{l}\text { I do warm up exer- } \\
\text { cises at the start of } \\
\text { my practice }\end{array}$ & $4.1(1.9)$ & $4.8(1.6)$ & $4.9(2.1)$ & $4.2(1.9)$ & $5.6(1.5)$ & $4.5(1.9)$ & $4.3(2.0)$ & $4.5(1.9)$ & .009 \\
\hline \multicolumn{10}{|l|}{ Analytic strategies } \\
\hline $\begin{array}{l}\text { I try to get an ove- } \\
\text { rall idea of a piece } \\
\text { before I practise it }\end{array}$ & $4.9(1.5)$ & $5.1(1.4)$ & $4.6(1.3)$ & $4.8(1.4)$ & $5.0(1.2)$ & $5.1(1.1)$ & $5.3(1.6)$ & $4.9(1.4)$ & NS \\
\hline $\begin{array}{l}\text { I think about how } \\
\text { I want to make the } \\
\text { music sound }\end{array}$ & $4.4(1.9)$ & $4.3(1.8)$ & 4.9 (1.6) & $4.7(1.8)$ & $4.7(2.0)$ & $4.7(1.7)$ & $4.6(1.7)$ & $4.6(1.8)$ & NS \\
\hline $\begin{array}{l}\text { When I'm practising } \\
\text { I mark things on the } \\
\text { part to help me }\end{array}$ & $3.9(1.8)$ & $3.9(1.7)$ & $4.0(1.5)$ & $4.1(1.9)$ & $4.3(1.6)$ & $3.7(1.8)$ & $3.8(2.0)$ & $3.9(1.8)$ & NS \\
\hline $\begin{array}{l}\text { I work things out } \\
\text { just by looking at } \\
\text { the music and not } \\
\text { playing }\end{array}$ & $3.5(1.7)$ & $3.9(1.6)$ & $3.5(1.4)$ & $4.0(1.3)$ & $3.5(.8)$ & $3.9(1.6)$ & $4.3(1.6)$ & $3.8(1.5)$ & NS \\
\hline
\end{tabular}




\begin{tabular}{|c|c|c|c|c|c|c|c|c|c|}
\hline $\begin{array}{l}\text { I try to find out } \\
\text { what a piece sounds } \\
\text { like before I begin } \\
\text { to try to play it }\end{array}$ & $5.0(1.7)$ & $5.0(1.4)$ & $5.1(1.4)$ & $4.5(1.5)$ & $5.3(1.2)$ & $4.6(1.7)$ & 5.3 (1.) & $4.8(1.5)$ & .032 \\
\hline $\begin{array}{l}\text { I analyse the } \\
\text { structure of a piece } \\
\text { before I learn to } \\
\text { play it }\end{array}$ & $4.1(1.5)$ & $3.9(1.9)$ & $4.0(1.1)$ & $3.9(1.7)$ & $3.4(1.3)$ & $4.2(1.5)$ & $4.3(1.5)$ & $4.0(1.6)$ & NS \\
\hline Concentration & & & & & & & & & NS \\
\hline $\begin{array}{l}\text { I am easily distrac- } \\
\text { ted when I practise }\end{array}$ & $3.8(1.6)$ & $4.0(1.9)$ & $4.3(1.4)$ & $3.9(1.8)$ & $3.6(1.9)$ & $3.6(1.9)$ & $3.6(1.7)$ & $3.9(1.8)$ & NS \\
\hline $\begin{array}{l}\text { I find it easy to } \\
\text { concentrate when I } \\
\text { practise }\end{array}$ & $5.1(1.4)$ & $5.2(1.3)$ & $5.0(.9)$ & $5.1(1.3)$ & $5.3(1.2)$ & $5.5(1.1)$ & $5.4(1.6)$ & $5.2(1.3)$ & NS \\
\hline Piano, keyboard & 4.1 & 4.4 & 4.6 & 16.5 & 41.6 & 55.5 & 22.1 & 23.0 & 43.5 \\
\hline \multicolumn{10}{|l|}{$\begin{array}{l}\text { Effective practice } \\
\text { strategies }\end{array}$} \\
\hline $\begin{array}{l}\text { I know when I have } \\
\text { made a mistake }\end{array}$ & $5.6(1.1)$ & $5.6(1.7)$ & $5.9(.8)$ & $5.3(1.7)$ & $5.7(1.2)$ & $5.7(1.3)$ & $5.8(2.2)$ & $5.6(1.5)$ & NS \\
\hline $\begin{array}{l}\text { When I make a } \\
\text { mistake I practise } \\
\text { the section where I } \\
\text { went wrong slowly }\end{array}$ & $5.5(1.3)$ & $5.4(1.6)$ & $5.4(.7)$ & $5.2(1.6)$ & $5.1(1.6)$ & $5.3(1.5)$ & $4.9(1.9)$ & $5.3(1.5)$ & NS \\
\hline $\begin{array}{l}\text { I practise things } \\
\text { slowly }\end{array}$ & $4.7(1.5)$ & $4.9(1.4)$ & $4.6(1.2)$ & $4.9(1.7)$ & $4.5(1.7)$ & $5.1(1.3)$ & $4.6(2.0)$ & $4.9(1.5)$ & NS \\
\hline $\begin{array}{l}\text { I learn by playing } \\
\text { slowly to start with } \\
\text { and then gradually } \\
\text { speeding up }\end{array}$ & $5.1(1.4)$ & $5.1(1.6)$ & $4.8(1.1)$ & $5.1(1.6)$ & $4.1(1.7)$ & $4.9(1.7)$ & $5.8(1.5)$ & $5.0(1.6)$ & NS \\
\hline $\begin{array}{l}\text { I work out where } \\
\text { the difficult sec- } \\
\text { tions are when I'm } \\
\text { learning a piece of } \\
\text { music }\end{array}$ & $4.8(1.8)$ & $5.2(1.4)$ & $5.4(.9)$ & $5.0(1.5)$ & $4.7(1.2)$ & $4.6(1.6)$ & $4.8(1.8)$ & $5.0(1.5)$ & NS \\
\hline $\begin{array}{l}\text { I practice small sec- } \\
\text { tions of the pieces I } \\
\text { am learning }\end{array}$ & $5.1(1.5)$ & $4.6(1.4)$ & $4.9(1.3)$ & $4.9(1.6)$ & $4.9(1,7)$ & $5.1(1.5)$ & $4.1(1.3)$ & $4.8(1.5)$ & NS \\
\hline $\begin{array}{l}\text { When something is } \\
\text { difficult I play it over } \\
\text { and over }\end{array}$ & $5.3(1.4)$ & $5.9(1.3)$ & $5.6(1.0)$ & $5.6(1.4)$ & $5.1(1.8)$ & $5.6(1.4)$ & $5.8(1.2)$ & $5.6(1.4)$ & NS \\
\hline \multicolumn{10}{|l|}{$\begin{array}{l}\text { Ineffective practi- } \\
\text { ce strategies }\end{array}$} \\
\hline $\begin{array}{l}\text { When I make a } \\
\text { mistake I go back } \\
\text { to the beginning of } \\
\text { the piece and start } \\
\text { again }\end{array}$ & $3.6(1.5)$ & $4.2(1.9)$ & $3.8(1.7)$ & 3.9 (1.9) & $4.2(1.6)$ & $4.2(1.7)$ & $3.6(1.7)$ & $4.0(1.8)$ & NS \\
\hline $\begin{array}{l}\text { When I practise I } \\
\text { only play pieces } \\
\text { from beginning } \\
\text { to end without } \\
\text { stopping }\end{array}$ & $3.5(1.6)$ & $3.7(1.4)$ & $4.1(1.7)$ & $3.3(1.7)$ & $3.4(1.2)$ & $3.9(1.6)$ & $3.3(1.9)$ & $3.6(1.6)$ & NS \\
\hline
\end{tabular}




\begin{tabular}{|l|c|c|c|c|c|c|c|c|c|}
\hline $\begin{array}{l}\text { When I make a } \\
\text { mistake I carry on } \\
\text { without correcting } \\
\text { it }\end{array}$ & $3.0(1.5)$ & $2.8(1.9)$ & $3.3(1.8)$ & $2.9(1.6)$ & $3.1(1.5)$ & $3.3(1.6)$ & $3.1(2.1)$ & $3.0(1.7)$ & $\mathrm{NS}$ \\
\hline $\begin{array}{l}\text { When I make a mis- } \\
\text { take, I stop, correct } \\
\text { the wrong note and } \\
\text { the carry on. }\end{array}$ & $4.9(1.7)$ & $5.1(1.6)$ & $5.2(1.1)$ & $5.0(1.7)$ & $4.7(1.4)$ & 4.6 & $4.3(1.8)$ & $4.9(1.7)$ & $\mathrm{NS}$ \\
\hline Use of resources & & & & & & $3.0)$ & & & \\
\hline $\begin{array}{l}\text { I practise with the } \\
\text { metronome }\end{array}$ & $3.2(1.4)$ & $3.0(1.9)$ & $3.6(1.6)$ & $3.0(1.8)$ & $3.0(1.6)$ & $3.0(1.7)$ & $3.0(1.7)$ & $3.0(1.7)$ & $\mathrm{NS}$ \\
\hline $\begin{array}{l}\text { I record myself } \\
\text { playing and listen to } \\
\text { the tapes }\end{array}$ & $3.0(1.7)$ & $2.4(1.7)$ & $3.3(1.7)$ & $2.9(1.6)$ & $3.1(1.4)$ & $2.9(1.7)$ & $3.1(2.3)$ & $2.8(1.7)$ & $\mathrm{NS}$ \\
\hline $\begin{array}{l}\text { I try to get a recor- } \\
\text { ding of the piece } \\
\text { that I am learning so } \\
\text { that I can listen to it }\end{array}$ & $3.5(1.8)$ & $3.4(1.8)$ & $3.7(1.6)$ & $3.7(1.9)$ & $4.0(1.6)$ & $4.1(2.0)$ & $3.9(2.3)$ & $3.7(1.9)$ & $\mathrm{NS}$ \\
\hline
\end{tabular}

Standard deviations are indicated in the bracketed figures

Table 5: Practice strategies by instrument group

Age: The multivariate analysis revealed a statistically significant difference in practice strategies in relation to age $(F(54,722)=1.46, p=.019)$. There were no statistically significant interactions between age and instrument group. The specific strategies where there were statistically significant differences in terms of age are set out in Table 6. These related to ineffective strategy use which reduced with age; 'thinking about how I want the music to sound' ( $p=018$ ); 'trying to get a recording of the piece that I am learning' ( $p=013)$ and 'marking things on the part' (.002), all of which increased with age.

Gender: The multivariate analysis of items by gender was not statistically significant. There was also no statistically significant interaction between instrument group, age and gender.

\begin{tabular}{|c|c|c|c|c|c|}
\hline $\mathrm{N}=451$ & $\mathbf{7 - 1 0}$ & $\mathbf{1 1 - 1 4}$ & $\mathbf{1 5 +}$ & Total & Sig \\
\hline $\begin{array}{c}\text { When I practise I only play pieces from the begin- } \\
\text { ning to the end without stopping }\end{array}$ & $3.8(1.7)$ & $3.6(1.6)$ & $3.1(1.2)$ & $3.6(1.6)$ & .021 \\
\hline $\begin{array}{c}\text { When I make a mistake, I go back to the beginning } \\
\text { of the piece and start again }\end{array}$ & $4.3(2.0)$ & $3.9(1.6)$ & $3.3(1.4)$ & $4.8(1.5)$ & .007 \\
\hline I think about how I want the music to sound & $4.2(2.0)$ & $4.5(1.8)$ & $5.0(1.4)$ & $4.5\left(1.8 \_\right.$ & .018 \\
\hline $\begin{array}{c}\text { I try to get a recording of the piece that I am lear- } \\
\text { ning so that I can listen to it }\end{array}$ & $3.4(2.0)$ & $3.6(1.8)$ & $4.4(1.7)$ & $3.7(1.9)$ & .013 \\
\hline $\begin{array}{c}\text { When I'm practising I mark things on the part to } \\
\text { help me }\end{array}$ & $3.6(1.9)$ & $4.3(1.7)$ & $4.0(1.5)$ & $3.9(1.8)$ & .002 \\
\hline
\end{tabular}

Standard deviations are indicated in the bracketed figures

Table 6: Practice strategies by age 


\section{Attitudes towards practice}

Multivariate analysis revealed no statistically significant differences for instrument group, age or gender or any interactions between them in relation to attitudes towards practice. Table 7 sets out the means for the different instrument groups.

\begin{tabular}{|l|c|c|c|c|c|c|c|c|c|}
\hline $\begin{array}{l}\text { Statement } \\
\mathrm{N}=451\end{array}$ & $\begin{array}{c}\text { Piano, } \\
\text { keyboard, }\end{array}$ & Woodwind & Brass & Strings & Voice & $\begin{array}{c}\text { Guitar } \\
\text { (all) }\end{array}$ & Drums & Total & Sig \\
\hline I like practising & $4.6(2.0)$ & $5.2(1.9)$ & $5.3(1.1)$ & $4.7(1.8)$ & $5.1(1.8)$ & $4.7(2.0)$ & $6.3(1.4)$ & $4.9(1.9)$ & NS \\
\hline $\begin{array}{l}\text { On some days } \\
\text { I don't want to } \\
\text { practise }\end{array}$ & $4.2(2.0)$ & $5.2(1.6)$ & $3.9(2.1)$ & $4.9(1.7)$ & $4.5(1.9)$ & $4.8(1.6)$ & $4.8(1.9)$ & $4.8(1.8)$ & NS \\
\hline $\begin{array}{l}\text { I find practising } \\
\text { boring }\end{array}$ & $3.2(2.3)$ & $3.4(2.1)$ & $3.5(2.0)$ & $3.3(1.9)$ & $4.8(1.9)$ & $3.4(1.9)$ & $2.6(2.1)$ & $\begin{array}{c}3.4 \\
(2.0)\end{array}$ & NS \\
\hline
\end{tabular}

Standard deviations are indicated in the bracketed figures

Table 7: Attitudes towards practice

\section{Motivation}

Instrument groups: The multivariate analysis showed overall statistical significance in relation to motivation and instrument group $(F(156,2208)=1.6, p=.0001)$. There were statistically significant differences in terms of perceptions that teachers at school liked the students to play their instrument. The strongest response to this came from the drummers $(M=6.3)$. The least positive responses were from the brass players $(M=$ 4.7) and the guitar players $(M=4.7)$. The overall mean was 5.1 suggesting that overall the beginners perceived a fairly high-level of support from teachers at school. Overall, support from parents was perceived as higher than that from teachers $(M=5.6)$ or other relatives $(M=5.5)$, although support from siblings was perceived as less $(M=4.5)$. There was also a belief that most people perceived that they played their instrument well ( $M$ $=5.2)$, although there were statistically significant differences here $(p=.01)$. The most positive response came from the singers $(M=5.6)$, the lowest from the piano/keyboard players ( $M=4.7)$ (see Table 8).

Overall, there was agreement that music formed part of respondents' social life ( $M$ $=4.7)$ and that they had a lot of friends who played instruments $(M=5.0)$. There were statistically significant differences in relation to going to concerts to listen $(p=.0001)$ with the highest scores from the guitarists $(M=5.4)$ and the lowest from the drummers $(M=3.9)$, also for enjoying playing in groups $(p=.009)$ with singers $(5.4)$ and string players (5.0) reporting enjoying this the most and piano/keyboard (3.6) and drums (3.8) the least.

String players and singers agreed most strongly that playing in concerts gave them 'a real thrill' (strings $M=5.1$, singers, $M=5.0$ ) and that they found it most satisfying to play in concerts (Singers $M=5.4$; Strings $M=5.2$ ). Overall, most of the beginners reported finding concert participation satisfying $(M=4.9)$ and thrilling $(M=4.6)$. Overall, the students reported enjoying playing their instrument $(M=5.7)$, although they were less 
enthusiastic about enjoying their lessons $(M=4.8)$. There were statistically significant differences in reported enjoyment of playing an instrument $(p=.027)$ with drummers (M $=6.6$ ) and woodwind players reporting enjoying it the most (6.0) and singers the least (5.2) (see Table 8).

There was strong agreement amongst the students that they had musical ability ( $M$ = 5.0); had the potential to be a good musician $(M=5.0)$; and were usually successful in what they attempted to do on their instrument $(M=5.1)$. They believed that they could achieve anything if they practiced enough $(M=5.5)$. There were no statistically significant instrument differences here.

Overall, there were strong positive responses to enjoying listening to music $(M=$ 6.0). This was responded to more positively than valuing playing an instrument $(M=5.3)$.

In relation to aspirations there were no statistically significant differences relating to always wanting to be involved in musical activities $(M=5.2)$, but there were for thinking that musical engagement would impact on their future career $(p=.031)$ with the strongest agreement from the guitar players $(M=5.0)$, drummers and string players $(M=4.9)$. The weakest responses were from the piano/keyboard players. There were also differences in terms of wanting to be a musician $(p=.001)$. The strongest responses to this statement came from the guitar players $(M=5.4)$. The least positive responses came from the pianists/keyboard players $(M=4.0)$ and brass players $(M=4.2)$ (see Table 8).

Age: The multivariate analysis revealed that there were statistically significant differences relating to age $(F(48,740)=1.4 p=.036)$. Perceptions that their parents wanted the young people to play an instrument declined with age, with a statistical significance of $p=.007$. All of the other elements which were statistically significant increased with age: finding it satisfying to play in concerts $(p=.028)$; finding it thrilling to play in concerts ( $p=.004)$; and enjoying playing in groups ( $p=.001)$. All of these are broadly linked with music becoming part of an individual's social life and support those items relating to the development of expertise more generally. There were no statistically significant interactions between instrument group and age.

Gender: The multivariate analysis of variance showed that overall there was a statistically significant impact of gender on motivation $(F(24,369)=1.7, p=.028)$. When the statistical significance of individual statements was considered there were differences relating to 'Most people think I play my instrument well' $(p=.004)$, where the girls had a higher mean score (Female $M=5.4$, Male $M=5.2)$; 'I have musical ability' $(p=.035)$ where the boys had stronger self-belief $(M=5.2$ girls 5.0); and 'I enjoy going to concerts to listen' ( $p=.013$ ) (Male $M=5.1$, Female $M=5.0$ ). Although these differences were statistically significant, they are very small. They should not be regarded with too much importance. There were no statistically significant interactions between instrument group, age and gender. 


\begin{tabular}{|c|c|c|c|c|c|c|c|c|c|}
\hline $\begin{array}{l}\text { Statement } \\
\mathrm{N}=450\end{array}$ & $\begin{array}{l}\text { Piano } \\
\text { keyboard }\end{array}$ & $\begin{array}{l}\text { Wood } \\
\text { Wind }\end{array}$ & Brass & Strings & Voice & Guitar (all) & Drums & Total & Sig \\
\hline \multicolumn{10}{|l|}{$\begin{array}{l}\text { Social support and } \\
\text { affirmation }\end{array}$} \\
\hline $\begin{array}{l}\text { My teachers at school } \\
\text { like me to play a musical } \\
\text { instrument }\end{array}$ & $5.1(1.5)$ & $5.3(1.7)$ & $4.7(2.0)$ & $5.0(1.6)$ & $5.0(1.6)$ & $4.7(1.7)$ & $6.3(1.1)$ & $5.1(1.7)$ & .016 \\
\hline $\begin{array}{l}\text { My parents want me to } \\
\text { play an instrument }\end{array}$ & $5.4(1.3)$ & $5.9(1.5)$ & $5.7(1.2)$ & $5.7(1.6)$ & $5.4(1.2)$ & $5.2(1.5)$ & $5.9(1.6)$ & $5.6(1.5)$ & NS \\
\hline $\begin{array}{l}\text { My brothers/sisters like } \\
\text { me playing a musical } \\
\text { instrument }\end{array}$ & $4.1(2.1)$ & $4.6(2.0)$ & $4.3(2.1)$ & $4.6(2.0)$ & $4.9(1.7)$ & $4.6(1.9)$ & $4.7(2.6)$ & $\begin{array}{c}4.5 \\
(2.0)\end{array}$ & NS \\
\hline $\begin{array}{l}\text { My relations (for } \\
\text { example grandparents, } \\
\text { aunts and uncles) like } \\
\text { me playing a musical } \\
\text { instrument }\end{array}$ & $5.0(2.0)$ & $\begin{array}{c}5.8 \\
(1.6)\end{array}$ & $5.2(1.6)$ & $5.6(1.5)$ & 5.9 (1.1) & $5.5(1.4)$ & $5.7(2.0)$ & $5.5(1.6)$ & NS \\
\hline $\begin{array}{l}\text { Most people think that I } \\
\text { play my instrument well }\end{array}$ & $4.7(1.9)$ & $5.5(1.6)$ & $5.0(1.1)$ & $5.4(1.4)$ & $5.6(1.0)$ & $4.9(1.6)$ & $5.2(2.0)$ & $5.2(1.6)$ & .01 \\
\hline \multicolumn{10}{|l|}{$\begin{array}{l}\text { Enjoyment of playing } \\
\text { an instrument }\end{array}$} \\
\hline $\begin{array}{l}\text { I enjoy playing my ins- } \\
\text { trument very much }\end{array}$ & $5.6(1.5)$ & $6.0(1.4)$ & $5.5(1.7)$ & $5.7(1.5)$ & $5.2(1.3)$ & $5.6(1.8)$ & $6.6(.8)$ & $5.7(1.5)$ & .027 \\
\hline $\begin{array}{l}\text { I enjoy my instrumental } \\
\text { lessons }\end{array}$ & $4.4(2.3)$ & $5.0(2.2)$ & $\begin{array}{l}3.9 \\
(2.6)\end{array}$ & $5.0(2.1)$ & $4.3(1.7)$ & $4.9(1.9)$ & $5.2(2.1)$ & $\begin{array}{c}4.8 \\
(2.2)\end{array}$ & NS \\
\hline \multicolumn{10}{|l|}{ Self-beliefs } \\
\hline $\begin{array}{l}\text { I can achieve anything I } \\
\text { want on my instrument } \\
\text { if I practise enough }\end{array}$ & $5.4(1.6)$ & $5.7(1.6)$ & $4.9(1.4)$ & $5.2(1.6)$ & $5.6(1.3)$ & $5.5(1.6)$ & $6.0(1.0)$ & $5.5(1.6)$ & NS \\
\hline $\begin{array}{l}\text { To succeed in playing } \\
\text { an instrument you need } \\
\text { musical ability }\end{array}$ & $4.4(1.6)$ & $4.6(2.0)$ & $4.8(1.6)$ & $4.6(1.7)$ & $5.4(1.0)$ & $4.5(1.9)$ & $4.6(1.5)$ & $4.6(1.8)$ & NS \\
\hline I have musical ability & $4.8(1.5)$ & $5.0(1.8)$ & $4.8(1.4)$ & $4.9(1.5)$ & $5.0(1.5)$ & $5.2(1.1)$ & $5.0(1.7)$ & $\begin{array}{r}5.0 \\
(1.5) \\
\end{array}$ & NS \\
\hline $\begin{array}{l}\text { I have the potential to } \\
\text { be a good musician }\end{array}$ & $4.7(1.6)$ & $5.0(1.7)$ & $4.6(1.5)$ & $5.2(1.5)$ & $\begin{array}{r}4.7 \\
(1.4) \\
\end{array}$ & $5.3(1.4)$ & $5.3(1.3)$ & $5.0(1.5)$ & NS \\
\hline $\begin{array}{l}\text { I am usually successful } \\
\text { in what I attempt to do } \\
\text { on my instrument }\end{array}$ & $4.9(1.5)$ & $5.4(1.6)$ & $5.1(1.5)$ & $4.9(1.5)$ & $5.4(2.1)$ & $5.1(1.4)$ & $5.6(1.0)$ & $5.1(1.5)$ & NS \\
\hline \multicolumn{10}{|l|}{ Musical aspirations } \\
\hline $\begin{array}{l}\text { I will always want to } \\
\text { be involved in musical } \\
\text { activities }\end{array}$ & $5.1(1.9)$ & $5.0(1.9)$ & $4.8(1.8)$ & $5.2(1.6)$ & $5.5(1.2)$ & $5.4(1.6)$ & $5.8(1.0)$ & $5.2(1.7)$ & NS \\
\hline $\begin{array}{l}\text { I think it will be useful to } \\
\text { my future career to play } \\
\text { a musical instrument }\end{array}$ & $4.2(2.0)$ & 4.7 (1.9) & $4.3(2.1)$ & $4.9(1.8)$ & $4.8(1.7)$ & $5.0(1.9)$ & $4.6(2.2)$ & $4.7(1.9)$ & .031 \\
\hline $\begin{array}{l}\text { I would like to become } \\
\text { a musician }\end{array}$ & $4.0(1.9)$ & $4.5(1.7)$ & $\begin{array}{c}4.2 \\
(2.0)\end{array}$ & $4.6(1.8)$ & $5.0(1.7)$ & $5.4(1.7)$ & $4.5(2.1)$ & $4.6(1.9)$ & .001 \\
\hline $\begin{array}{l}\text { Music as part of social } \\
\text { life }\end{array}$ & & & & & & & & & \\
\hline
\end{tabular}




\begin{tabular}{|c|c|c|c|c|c|c|c|c|c|}
\hline $\begin{array}{l}\text { Playing an instrument is } \\
\text { an important part of my } \\
\text { social life }\end{array}$ & $4.5(1.6)$ & $4.7(1.8)$ & $4.5(1.4)$ & $4.7(1.7)$ & 4.9 (1.5) & 4.9 (1.9) & 4.5 (1.9) & 4.7 (1.7) & NS \\
\hline $\begin{array}{l}\text { I have a lot of friends } \\
\text { who play musical ins- } \\
\text { truments }\end{array}$ & $4.5(2.0)$ & $5.2(1.9)$ & $5.2(1.7)$ & 4.9 (1.9) & $5.1(1.5)$ & $5.1(1.5)$ & $5.5(1.6)$ & $5.0(1.8)$ & NS \\
\hline $\begin{array}{l}\text { I enjoy playing in musi- } \\
\text { cal groups, orchestras } \\
\text { and bands }\end{array}$ & $3.6(2.3)$ & $4.4(2.2)$ & $4.5(1.8)$ & $5.0(1.8)$ & 5.4 (1.4) & 4.6 (1.9) & $3.8(2.7)$ & 4.5 (2.1) & .009 \\
\hline $\begin{array}{l}\text { I enjoy going to con- } \\
\text { certs to listen }\end{array}$ & $4.3(2.1)$ & $5.0(1.8)$ & 4.5 (1.9) & $5.2(1.7)$ & $5.2(1.4)$ & $5.4(1.7)$ & $3.9(2.4)$ & 4.9 (1.8) & .0001 \\
\hline \multicolumn{10}{|l|}{ Value placed on music } \\
\hline $\begin{array}{l}\text { I think it is valuable to } \\
\text { play a musical instru- } \\
\text { ment }\end{array}$ & $4.6(2.0)$ & $5.1(1.8)$ & $\begin{array}{l}4.9 \\
(2.0)\end{array}$ & $5.6(1.4)$ & $5.6(.9)$ & $5.3(1.8)$ & $5.5(2.1)$ & $\begin{array}{l}5.3 . \\
(1.7)\end{array}$ & NS \\
\hline $\begin{array}{l}\text { I enjoy listening to } \\
\text { music }\end{array}$ & $5.9(1.3)$ & $6.1(1.3)$ & $5.9(1.3)$ & $6.0(1.3)$ & $5.9(2.0)$ & 5.9 (1.4) & $6.1(1.5)$ & $6.0(1.4)$ & NS \\
\hline \multicolumn{10}{|l|}{ Performance } \\
\hline $\begin{array}{l}\text { I find it very satisfying } \\
\text { to play in concerts }\end{array}$ & $4.3(2.0)$ & $4.7(2.1)$ & $5.0(1.5)$ & $5.2(1.8)$ & $5.4(1.2)$ & 4.9 (1.9) & $5.1(2.0)$ & 4.9 (1.9) & .021 \\
\hline $\begin{array}{l}\text { Playing in concerts } \\
\text { gives me a real thrill }\end{array}$ & $4.1(2.1)$ & $4.1(2.2)$ & $4.6(1.3)$ & $5.1(1.8)$ & $5.0(1.4)$ & $4.5(2.2)$ & $4.7(2.2)$ & $\begin{array}{c}4.6 \\
(2.0)\end{array}$ & .035 \\
\hline
\end{tabular}

Standard deviations are indicated in the bracketed figures

Table 8: Motivation by instrument group

\section{Discussion}

Overall, the findings revealed the complexity of attempting to establish differences between instrument groups relating to practice and motivation. While the univariate and multivariate analyses indicated strong, overall, statistically significant differences between instrument groups there were relatively few differences in relation to specific statements and, in some cases, these were mediated by age.

When examining the statements relating to time spent practicing there were statistically significant instrument and age differences. When the relationship between instrument group and age was considered a complex picture emerged. At age 7-10 the singers reported doing no practice and the drummers very little while the other instrumentalists were completing between 15 to 30 minutes each day. Between ages 11-14, the amount of practice had increased substantially, although the singers were still doing the least practice by quite a large margin. Over the age of 15 years, the woodwind players reported doing the least practice each day followed by the singers. The most practice was reported by the string players and guitar players, over an hour each day. There may be a number of reasons for the differences in practice time. Perhaps some instruments are less physically demanding in the early stages of learning or are more musically satisfying because they offer the opportunity for melody and harmony. Further research is required to explore this issue. Across all ages the singers were amongst those doing the least practice. This may be because they, or their teachers, perceive 
a need to protect the voice, supported by their responding most positively to starting their practice with warm up exercises. More research is needed to explore this issue. It is surprising that the woodwind and brass players did not seem to engage in warm up exercises to the same extent as the singers. Of course, this may be an artefact of the specific sample studied. Whether this is the case or not, all instrumental teachers need to ensure that they teach in such a way as to encourage healthy practicing in order to avoid learners developing physical injuries which can affect their long-term continuation of engagement with playing.

Overall, the beginners typically did not set targets for each practice session or make lists of what they had to practice. This is likely to have an impact on the effectiveness of practice. To encourage effective practice, teachers should try to ensure that learners understand what they need to improve, what they should be practising and help them set realistic targets.

The drummers, along with the singers, were the most likely to learn the sound of the piece to be learned before practicing it. This suggests that these groups may have been learning to play by ear rather than from notation. Generally, musicians need to develop a wide range of skills including playing by ear and reading notation. The strategies used by singers and drummers might be explored and used to support other instrumentalists in learning to play by ear. Teachers might include playing by ear from recordings during instrumental lessons as a means to support learners' aural, improvisatory and creative musicianship skills (VARVARIGOU, 2017).

Overall, the practice strategies adopted tended to be those which were more rather than less effective. This differs from what might have been expected based on the previous research (GRUSON, 1988; HALLAM, 1997; HALLAM et al., 2012; MCPHERSON; RENWICK, 2001; PITTS et al., 2000a). There are a number of possible reasons for this. Firstly, learners frequently report adopting learning strategies before they actually do so (FLAVELL, 1976). Secondly, the age range of these beginners was wider than those participating in the previous research which tended to focus on younger beginners. These older beginners may have already acquired a wide range of learning strategies in other subjects which they were able to apply to their instrumental practice. Certainly, the age related analysis showed that the adoption of ineffective strategies declined in the older age groups, while there was an increase in thinking about how participants wanted the music to sound, marking things on the part and getting a recording of the piece they were learning. Thirdly, although they had not yet taken their first graded examination or still judged their performance as pre-Grade 1 some participants had been learning for over two years. This would have allowed them time to develop effective practice strategies. The findings relating to the use of the metronome and self-recordings to improve performance reflected earlier findings in that these strategies were infrequently used by beginners (HALLAM et al., 2012). However, the responses suggested that the participants had more opportunities to listen to recordings of the music they were to learn. This may reflect the increased availability of learning materials for beginners which include recordings of what is to be learned and backing tracks. It is likely that these resources help learners in the early stages of learning to develop appropriate schemata 
which should reduce the number of errors that they make and the need for relearning when errors have become automated and need to be unlearned before they can be corrected.

Perceptions of support from parents and other relatives, for instance, grandparents, were strong across all instruments. Less support was perceived from siblings and school teachers. The drummers perceived that they received the greatest support from their school teachers. This may be an artefact of the sampling, but it is also worthy of further research. Most respondents perceived that others thought that they played their instruments well. The most positive responses were from the singers, the least from the pianists. There may be a number of reasons for this. Perhaps, the relative technical ease of singing in the early stages may contribute to positive perceptions of its quality, while the more challenging techniques required in playing an instrument may lead to less positive evaluations by others. Further research is needed to elucidate this issue.

Overall, the participants indicated that they had friends who played instruments. The string players and singers reported enjoying playing and singing with others the most suggesting that musical activities had become an important part of their social lives. This is important in developing a musical identity, which in turn supports ongoing commitment to music. To sustain motivation in the long term, teachers need to try to provide opportunities for learners to develop a range of social musical activities. These may be in large or small groups, informal or formal. Of all the instruments, the opportunities for making music with others are less apparent for those playing piano/keyboard. It may be that the opportunity to have a holistic musical experience through keyboard playing does not sufficiently compensate for social interactions. For sustained motivation, teachers need to be creative in encouraging those playing the piano or keyboard to make music with others.

The string players and singers also reported the greatest enjoyment of performing. This may be associated with group performances which are generally considered to be less stressful than solo performances. Despite this, there was general agreement that performance was thrilling and enjoyable. To support motivation, teachers need to take account of this and give students opportunities to perform as this creates opportunities where students can receive positive affirmation from others. Of course, there are some learners who dislike performing and experience debilitating performance anxiety. Teachers need to know their pupils well enough to assess which of these applies and make decisions about whether performance is appropriate and what kind of performance, formal or informal may best meet learners' needs.

Respondents, overall, reported enjoying listening to music more than valuing playing an instrument. This suggests that participants were developing love of music for its own sake. This has been repeatedly shown to be important in sustaining motivation in the long term (for a review see HALLAM; BURNS, 2018)

Although, overall, the students reported enjoying playing their instrument, they tended to be less enthusiastic about enjoying their lessons. There may be many reasons for this. Playing their instrument may be viewed as a more personal or creative musical experience, whereas lessons may seem to focus more on technique. Earlier research 
based on observations of one-to-one teaching suggest that lessons are dominated by teacher talk and students playing with few opportunities for them to contribute their views which may lead to passive learning as opposed to active participation with the scope for making choices, problem-solving and exploring imaginative ideas. Teachers tend not to demonstrate or praise students (HALLAM, 1998; KENNELL, 2002). In part this is because the immediate nature of musical sound as students play means that teachers can identify errors immediately and provide feedback. While this supports learning, it can lead to lessons focusing on criticism with less emphasis on praise for improvement. To avoid this, teachers need to ensure that they balance constructive criticism with praise. Teaching in small or large groups presents different challenges but may mean that there is little opportunity for attention being given to individuals (HALLAM, 2012).

The participants, overall, had strong positive self-beliefs about their musical potential. They believed that musical ability was necessary for success and that they had musical ability. They also believed that they could be successful in any musical activity if they worked sufficiently hard. This suggests that they held mastery and performance goals, recognising the importance of effort while maintaining positive self-efficacy (DWECK, 1986). The adoption of mastery goals is crucial for maintaining motivation as learners set themselves personal goals to achieve (HALLAM, 2016).

Overall, the participants agreed that they would always want to be involved in making music. There was less agreement that being involved in music would help their career and that they wanted to become a professional musician. Those most strongly agreeing that they wanted to become a musician and that music would be most useful in their career were the guitarists, those agreeing the least were the pianists. There may be many reasons for these differences. The most likely relate to the availability of role models in the media, where guitar players are more common than pianists, string, brass or woodwind players. However, this does not explain why the guitarists were more positive about a career in music than the singers or drummers who are frequently seen in the media. This requires further research.

Interestingly, the instruments played by the participants reflected the gender preferences well established in other research (e.g. ABELES, 2009; HALLAM; ROGERS; CREECH, 2008; KILLIAN; SATROM, 2011; SHELDON; PRICE, 2005; WYCH, 2012; HALLAM et al., 2017) The least gendered instruments were piano and keyboard. The girls predominantly played woodwind and stringed instruments and were singers. The boys typically played guitar, drums and to a lesser extent brass instruments. Why this gendering of instruments continues when such gendering is changing in other walks of life is puzzling and requires further research. To encourage children to take up a wide range of instruments regardless of their gender, teachers need to ensure that they do not act in ways which may deter either boys or girls from beginning and continuing to play any specific instrument. Within the context of the multivariate analysis few gender differences emerged. There were none in relation to practicing. In terms of motivation the girls perceived more strongly that other people believed that they played their instrument well, while the boys were more confident that they had musical ability. This lack of musical self-belief in girls reflects earlier findings (HALLAM et al., 2016). The boys also 
reported enjoying going to concerts to listen more than the girls. Why this should be the case requires further exploration.

The findings reported here are limited in some respects. First, it may be that the concept of practicing was understood differently across the different groups. For example, some of the respondents may have conceptualized practicing as a solely individual activity, while others may have included strategies and approaches that they used in group contexts. A second related limitation is that some respondents may have been supervised in their practice, for example by a parent or a sibling. In such instances, this may have influenced the time spent practicing as well as the strategies adopted. Finally, all self-report questionnaires are limited in that the findings represent perceptions of behaviour, and there may be gaps between these perceptions and the actual time spent practicing or strategies implemented in practice. Nonetheless, the analysis reported here has revealed some important implications for understanding how children and young people may be supported in engaging with instrumental and vocal practicing, for example, pointing to the importance of modelling warm-up routines, the potential value of instrument groups sharing their strategies and learning from one another how to practice most effectively, and the importance of integrating ensemble and performance opportunities into instrumental and vocal learning.

To conclude, there were few differences between instruments in terms of practice and motivation for this sample of beginners. Overall, they reported adopting effective practicing strategies, although they did not tend to set targets for each session and with the exception of the singers there was little emphasis on warming up. The differences reported seemed to reflect the nature of the instrument itself, the repertoire and the nature of learning (by ear or through notation). While love of music was demonstrated through enjoyment of listening, the value placed on playing an instrument varied and seemed stronger for those who engaged in making music with others. They also seemed to enjoy performing more, perhaps because their musical learning included participation in an ensemble. Given the importance of music being part of an individual's social life in supporting the development of a musical identity, if teachers wish their students to continue playing an instrument they need to find ways to encourage learners to engage in ensemble activities, formally or informally.

\section{References}

ABELES, H. F. Are musical instrument gender associations changing? Journal of Research in Music Education, v. 57, n. 2, p. 127-139, 2009.

ASMUS, E. P. Motivation in music teaching and learning. The Quarterly Journal of Music Teaching and Learning, v. 5, p. 5-32, 1994.

AUSTIN, J. R.; RENWICK, J.; MCPHERSON, G. E. Developing Motivation. In: MCPHERSON, G .E. (Ed.). The child as musician: A handbook of musical development. Oxford: Oxford University Press, 2006, p 213-238. 
AUSTIN, J. R.; VISPOEL, W. P. How American adolescents interpret success and failure in classroom music: Relationships among attributional beliefs, self-concepts and achievement. Psychology of Music, v. 26, p. 26-45, 1998.

BAKKER, A. B. Flow among music teachers and their students: The crossover of peak experiences. Journal of Vocational Education, v. 66, n. 1, p. 26-44, 2005.

BARRY, N. H. The effects of practice strategies, individual differences in cognitive style, and gender upon technical accuracy and musicality of student instrumental performance. Psychology of Music, v. 20, p. 112-123, 1992.

BURLAND, K.; DAVIDSON, J. W. Training the talented. Music Education Research, v. 4, n. 1, p. 121-40, 2002.

CASSIE, V. K. Music makers: strings - teaching strategies for beginner orchestra class: Integrating seating arrangements and flow experience. Canadian Music Educator, v. 49, n. 4 , p. $50-51,2008$.

COSTA-GIOMI, E.; FLOWERS, P. J.; SASAKE, W. Piano lessons of beginning students who persist or drop out: Teacher behavior, student behavior and lesson progress. Journal of Research in Music Education, v. 33, n. 3, p. 234-247, 2005.

CREECH, A. The role of the family in supporting learning. In: HALLAM, S.; CROSS, I; THAUT, M. (Eds.). Oxford Handbook of Music Psychology. Oxford: Oxford University Press, 2009, p. 295-306.

CREECH, A.; HALLAM, S. Parent-teacher-pupil interactions in instrumental music tuition: a literature review. British Journal of Music Education, v. 20, n. 1, p. 29-44, 2003.

CREECH, A.; HALLAM, S. Learning a musical instrument: the influence of interpersonal interaction on outcomes for school-aged pupils. Psychology of Music, v. 39, n. 1, p. 102-122, 2011.

CREECH, A. et al. From music student to professional: The process of transition. British Journal of Music Education, v. 25, n. 3, p. 315-331, 2008.AVIDSON, J. W. et al. The role of parental influences in the development of musical ability. British Journal of Developmental Psychology, v. 14, n. 4, p. 399-412, 1996.

DAVIDSON, J. W. et al. Characteristics of music teachers and the progress of young instrumentalists. Journal of Research in Music Education, v.46, p.141-160, 1998.

DWECK, C. S. Motivational processes affect learning. American Psychologist, v.41, p.1040-1048, 1986. 
DUKE, R. A.; FLOWERS, P. J.; WOLFE, D. E. Children who study with piano with excellent teachers in the United States. Bulletin of the Council for Research in Music Education, n. 132, p. 51-84, 1997.

ERICSSON, K. A.; KRAMPE, R. T.; TESCH-ROMER, C. The role of deliberate practice in the acquisition of expert performance. Psychological Review, v. 100, n. 3, p. 363-406, 1993.

EVANS, P.; MCPHERSON, G. E.; DAVIDSON, J. W. The role of psychological needs in ceasing music and music learning activities. Psychology of Music, v. 41, n. 5, p. 600619, 2013.

FLAVELL, J. H. Metacognitive Aspects of Problem Solving. In: RESNICK, L. B. (Ed.). The Nature of Intelligence. Hillsdale. NJ: Earlbaum, Wiley, 1976, p. 231-35.

GRUSON, L. M. Rehearsal skill and musical competence: Does practice make perfect? In: SLOBODA, J. A. (Ed.). Generative processes in music: The psychology of performance, improvisation, and composition. Oxford: Clarendon Press, 1988, p. 91-112.

HALLAM, S. Professional musicians' orientations to practice: implications for teaching, British Journal of Music Education, v. 2, n. 1, p. 3-19, 1995.

HALLAM, S. Approaches to instrumental music practice of experts and beginners: Implications for Education, In: JØRGENSEN, H.; LEHMAN, A. C. (Eds.). Does practice make perfect? Current theory and research on instrumental music practice. Norges musikkhogskole: Oslo, 1997, p. 89-108.

HALLAM, S. Instrumental teaching. Oxford: Heinemann, 1998.

HALLAM, S. Musical Motivation: Towards a Model Synthesising the Research. Music Education Research, v. 4, n. 2, p. 225-244, 2002.

HALLAM, S. Commentary: Instrumental Music. In: MCPHERSON, G.; WELCH, G. (Eds.). Oxford Handbook of Music Education. Oxford: Oxford University Press, 2012, p. 651-657.

HALLAM, S. What predicts level of expertise attained, quality of performance, and future musical aspirations in young instrumental players? Psychology of Music, v. 41, n. 3, p. 265-289, 2013.

HALLAM, S. Motivation to learn. In: HALLAM, S.; CROSS, I.; THAUT, M. (Eds.). Handbook of Psychology of Music (2nd ed.). Oxford: Oxford University Press, 2016, p. 479-492. HALLAM, S.; BURNS, S. Progression in instrumental music making for learners from disadvantaged communities: A literature review. Leeds: Opera North/Arts Council England, 2018. 
HALLAM, S. et al. Changes in motivation as expertise develops: Relationships with musical aspirations. Musicae Scientiae, v. 20, n. 4, p. 528-550, 2016.

HALLAM, S. et al. Are there gender differences in instrumental music practice? Psychology of Music, v. 45, n. 1, p. 116-130, 2017.

HALLAM, S. et al. The development of practicing strategies in young people. Psychology of Music, v. 40, n. 5, p. 652-680, 2012.

HALLAM, S.; ROGERS, L.; CREECH, A. Gender differences in musical instrument choice. International Journal of Music Education, v. 26, n. 1, p. 7-19, 2008.

HARNISCHMACHER, C. The effects of individual differences in motivation, volition, and maturational processes on practice behaviour of young instrumentalists. In: JØRGENSEN, H.; LEHMAN, A. (Eds.). Does practice make perfect? Current theory and research on instrumental music practice. Norges musikkhgskole, Oslo, 1997, p. 71-88.

HOWE, M. J. A.; SLOBODA, J. A. Young musicians' accounts of significant influences in their early lives 1. The family and the musical background. British Journal of music Education, v. 8, p. 39-52, 1991.

JØRGENSENH. Time for practicing? Higher level music students' use of time for instrumental practicing. In: JØRGENSEN H.; LEHMAN, A. (Eds.). Does practice make perfect? Current theory and research on instrumental music practice. Norges musikkhgskole: Oslo, 1997, p. 123-140.

JØRGENSEN, H. Planlegges oving? (Is practice planned?). Oslo: Norweigian Academy of Music, 1998.

JØRGENSEN, H. Instrumental performance expertise and amount of practice among instrumental students in a conservatoire. Music Education Research, v. 4, p. 105-119, 2002.

JØRGENSEN, H.; HALLAM, S. Practicing. In: HALLAM S.; CROSS, I.; THAUT, M. (Eds.). Oxford Handbook of Music Psychology (2nd ed.). Oxford: Oxford University Press, 2016, p. $449-462$.

KENNELL, R. Systematic research in studio instruction in music. In: COLWELL, R; RICHARDSON, C. (Eds.). The new handbook of research on music teaching and learning. Oxford: Oxford University Press, 2002, p. 243-256.

KEMP, A. The musical temperament: Psychology and Personality of Musicians. Oxford: Oxford University Press, 1996. 
KILLIAN, J. N.; SATROM, S. L. The effect of demonstration gender on wind instrument preference of kindergarten, third-grade and fifth-grade students, Update: Applications of Research in Music Education, v. 29, n. 2, p. 13-19, 2011.

LAMMERS, M.; KRUGER, M. Brass and Woodwind Student Practice Habits in Norway, Japan, and the United States. NACWAPI (National Association of Wind and Percussion Instructors) Journal, Summer 2006, v. 54, n. 4, p. 4-13, 2006.

LAMONT, A. Musical identities and the school environment. In: MACDONALD, R. A. R.; HARGREAVES, D. J.; MIELL, D. (Eds.). Musical Identities. Oxford: Oxford University Press, 2002, p. 41-59.

LEGETTE, R.M. The effect of instruction on student self-concept and motivation. Missouri Journal of Research in Music Education, v. 40, p. 4-15, 2003.

MACNAMARA, A.; HOLMES, P.; COLLINS, D. The pathway to excellence: the role of psychological characteristics in negotiating the challenges of musical development. British Journal of Music Education, v. 23, p. 285-302, 2006.

MANTURZEWSKA, M. A biographical study of the life-span development of professional musicians. Psychology of Music, v. 18, p. 112-139, 1990.

MCPHERSON, G. E.; MCCORMICK, J. The contribution of motivational factors to instrumental performance in a performance examination. Research Studies in Music Education, v. 15, n. 1, p. 31-39, 2000.

MCPHERSON, G.; RENWICK, J. Longitudinal study of self-regulation in children's music practice. Music Education Research, v. 3, n. 1, p. 169-186, 2001.

MOORE, D. G.; BURLAND, K.; DAVIDSON, J. W. The social context of musical success: A developmental account. British Journal of Psychology, v. 94, n. 4, p. 529-549, 2003.

O'NEILL, S. A. The self-identity of young musicians. In: MACDONALD, R. A. R.; HARGREAVES, D. J.; MIELL, D. (Eds.). Musical Identities. Oxford: Oxford University Press, 2002, p. 79-96.

O'NEILL, S. A.; MCPHERSON, G. E. Motivation. In: PARNCUTT, R.; MCPHERSON, G. E. (Eds.). The Science and Psychology of Musical Performance: Creative Strategies for Teaching and Learning. New York: Oxford University Press, 2002, p. 31-46.

PATRICK, H. et al. Adolescents' commitment to developing talent: The role of peers in continuing motivation for sports and the arts, Journal of Youth and Adolescence, v. 28, n. 6, p. 741-763, 1999. 
PITTS, S.; DAVIDSON, J.; MCPHERSON, G. E. Developing effective practicing strategies: Case studies of three young instrumentalists. Music Education Research, v. 2, n. 1, p. 45-56, 2000a.

PITTS, S. E.; DAVIDSON, J. W.; MCPHERSON, G. E. Models of success and failure in instrumental learning: Case studies of young players in the first 20 months of learning. Bulletin of the Council for Research in Music Education, n. 146, p. 51-69, 2000b.

PRICE, H. E. Sequential patterns of music instruction and learning to use them. Journal of Research in Music Education, v. 40, n. 1, p.14-29, 1992.

SHELDON, D. A.; PRICE, H. E. Sex and Instrumentation distribution in an international cross-section of wind and percussion ensembles. Bulletin of the Council for Research in Music Education, n. 163, p. 43-51, 2005.

SICHIVITSA, V. O. The influences of parents, teachers, peers and other factors on students' motivation in music. Research Studies in Music Education, v. 29, n. 1, p. 55-68, 2007.

SLOBODA, J. A. et al. The role of practice in the development of performing musicians. British Journal of Psychology, v. 87, p. 287-309, 1996.

SLOBODA, J. A.; HOWE, M. J. A. Biographical precursors of musical excellence: an interview study. Psychology of Music, v. 19, p. 3-21, 1991.

SOSNIAK, L. A. Learning to be a concert pianist. In: BLOOM, B. S. (Ed). Developing talent in young people. New York: Ballentine, 1985, p. 19-67.

STGEORGE, J. The subjectivity of musical learning: Understanding participation in instrumental music instruction. Unpublished PhD, University of Newcastle, New South Wales, 2010.

SZUBERTOWSKA, E. Education and the Music Culture of Polish Adolescence. Psychology of Music, v. 33, n. 3, p. 317-330, 2005.

WYCH, G. M. F. Gender and instrument associations, stereotypes and stratification: a literature review. Update: Applications of Research in Music Education, v. 30, n. 2, p.22-31, 2012.

VARVARIGOU, M. Nurturing the twenty-first century musician through playing by ear from recordings in one to one and small group instrumental lessons. In: LOPES, E. (Ed.). Research Themes for the learning of musical instruments. Goiânia: Editora Kelps, 2017, p. 171-196. 
ZDINSKI, F. S. Parental involvement, selected student attributes and learning outcomes in instrumental music. Journal of Research in Music Education, v. 44, n. 1, p.34-38, 1996. 


\section{Appendix}

\section{Research on instrumental motivation and practice}

We are conducting some research on instrumental practicing. We would be very grateful if you would complete this questionnaire. It will take you about 10 minutes. Thank you for your time.

Name

Age

Main instrument

Other instruments

Do you take part in musical groups at school, e.g. orchestra, band? Yes / No If yes, please indicate what the groups are

Do you take part in musical groups out of school, e.g. county groups, community groups? Yes / No

If yes, please indicate what the groups are

On average how many days a week do you practice?

On average, how much practice do you do on each day?

How long have you been learning your first instrument? years months

What is the most recent grade examination you have taken?

What mark did you get? 
(please include the maximum that you could have attained, e.g. 71/100 or

$121 / 150$

Please indicate in the table below how strongly you agree or disagree with the following statements. Please answer ONLY in relation to your main instrument.

\begin{tabular}{|c|c|c|c|c|c|c|c|}
\hline & $\begin{array}{c}\text { Very } \\
\text { strongly agree }\end{array}$ & $\begin{array}{l}\text { Strongly } \\
\text { agree }\end{array}$ & Agree & Neutral & Disagree & $\begin{array}{l}\text { Strongly } \\
\text { disagree }\end{array}$ & $\begin{array}{c}\text { Very strongly } \\
\text { disagree }\end{array}$ \\
\hline \multicolumn{8}{|l|}{ Practicing strategies } \\
\hline \multicolumn{8}{|l|}{$\begin{array}{l}\text { I try to get an overall } \\
\text { idea of a piece before I } \\
\text { practice it }\end{array}$} \\
\hline \multicolumn{8}{|l|}{$\begin{array}{l}\text { When I practice I only } \\
\text { play pieces from be- } \\
\text { ginning to end without } \\
\text { stopping }\end{array}$} \\
\hline \multicolumn{8}{|l|}{$\begin{array}{l}\text { I work things out just } \\
\text { by looking at the mu- } \\
\text { sic and not playing }\end{array}$} \\
\hline \multicolumn{8}{|l|}{$\begin{array}{l}\text { I try to find out what } \\
\text { a piece sounds like } \\
\text { before I begin to try to } \\
\text { play it }\end{array}$} \\
\hline \multicolumn{8}{|l|}{$\begin{array}{l}\text { I work out where the } \\
\text { difficult sections are } \\
\text { when I'm learning a } \\
\text { piece of music }\end{array}$} \\
\hline \multicolumn{8}{|l|}{$\begin{array}{l}\text { I practice small } \\
\text { sections of the pieces I } \\
\text { am learning }\end{array}$} \\
\hline \multicolumn{8}{|l|}{$\begin{array}{l}\text { When I make a mis- } \\
\text { take, I stop, correct the } \\
\text { wrong note and then } \\
\text { carry on }\end{array}$} \\
\hline \multicolumn{8}{|l|}{$\begin{array}{l}\text { I try to get a recording } \\
\text { of the piece that I am } \\
\text { learning so that I can } \\
\text { listen to it }\end{array}$} \\
\hline \multicolumn{8}{|l|}{$\begin{array}{l}\text { I analyse the structu- } \\
\text { re of a piece before I } \\
\text { learn to play it }\end{array}$} \\
\hline \multicolumn{8}{|l|}{ I practice things slowly } \\
\hline \multicolumn{8}{|l|}{$\begin{array}{l}\text { I know when I have } \\
\text { made a mistake }\end{array}$} \\
\hline \multicolumn{8}{|l|}{$\begin{array}{l}\text { When I make a mistake } \\
\text { I practice the section } \\
\text { where I went wrong } \\
\text { slowly }\end{array}$} \\
\hline $\begin{array}{l}\text { When something is } \\
\text { difficult I play it over } \\
\text { and over again }\end{array}$ & & & & & & & \\
\hline
\end{tabular}




\begin{tabular}{|c|c|c|c|c|c|c|c|}
\hline $\begin{array}{l}\text { I learn by playing } \\
\text { slowly to start with } \\
\text { and then gradually } \\
\text { speeding up }\end{array}$ & & & & & & & \\
\hline $\begin{array}{l}\text { When I make a mistake } \\
\text { I go back to the begin- } \\
\text { ning of the piece and } \\
\text { start again }\end{array}$ & & & & & & & \\
\hline $\begin{array}{l}\text { When I'm practicing } \\
\text { I mark things on the } \\
\text { part to help me }\end{array}$ & & & & & & & \\
\hline $\begin{array}{l}\text { I practice with the } \\
\text { metronome }\end{array}$ & & & & & & & \\
\hline $\begin{array}{l}\text { When I make a mistake } \\
\text { I carry on without } \\
\text { correcting it }\end{array}$ & & & & & & & \\
\hline $\begin{array}{l}\text { I record myself playing } \\
\text { and listen to the tapes }\end{array}$ & & & & & & & \\
\hline $\begin{array}{l}\text { I think about how I } \\
\text { want to make the } \\
\text { music sound }\end{array}$ & & & & & & & \\
\hline $\begin{array}{l}\text { Organisation of } \\
\text { practice }\end{array}$ & & & & & & & \\
\hline $\begin{array}{l}\text { I start my practice with } \\
\text { scales }\end{array}$ & & & & & & & \\
\hline $\begin{array}{l}\text { I start my practice with } \\
\text { studies }\end{array}$ & & & & & & & \\
\hline $\begin{array}{l}\text { I do warm up } \\
\text { exercises at the start of } \\
\text { my practice }\end{array}$ & & & & & & & \\
\hline $\begin{array}{l}\text { I make a list of what I } \\
\text { have to practice }\end{array}$ & & & & & & & \\
\hline $\begin{array}{l}\text { I set myself targets to } \\
\text { achieve in each } \\
\text { practice session }\end{array}$ & & & & & & & \\
\hline Concentration & & & & & & & \\
\hline $\begin{array}{l}\text { I am easily distracted } \\
\text { when I practice }\end{array}$ & & & & & & & \\
\hline $\begin{array}{l}\text { I find it easy to } \\
\text { concentrate when I } \\
\text { practice }\end{array}$ & & & & & & & \\
\hline $\begin{array}{l}\text { Attitudes towards } \\
\text { practicing }\end{array}$ & & & & & & & \\
\hline I like practicing & & & & & & & \\
\hline $\begin{array}{l}\text { On some days I don't } \\
\text { want to practice }\end{array}$ & & & & & & & \\
\hline I find practicing boring & & & & & & & \\
\hline $\begin{array}{l}\text { Social support and } \\
\text { affirmation }\end{array}$ & & & & & & & \\
\hline
\end{tabular}




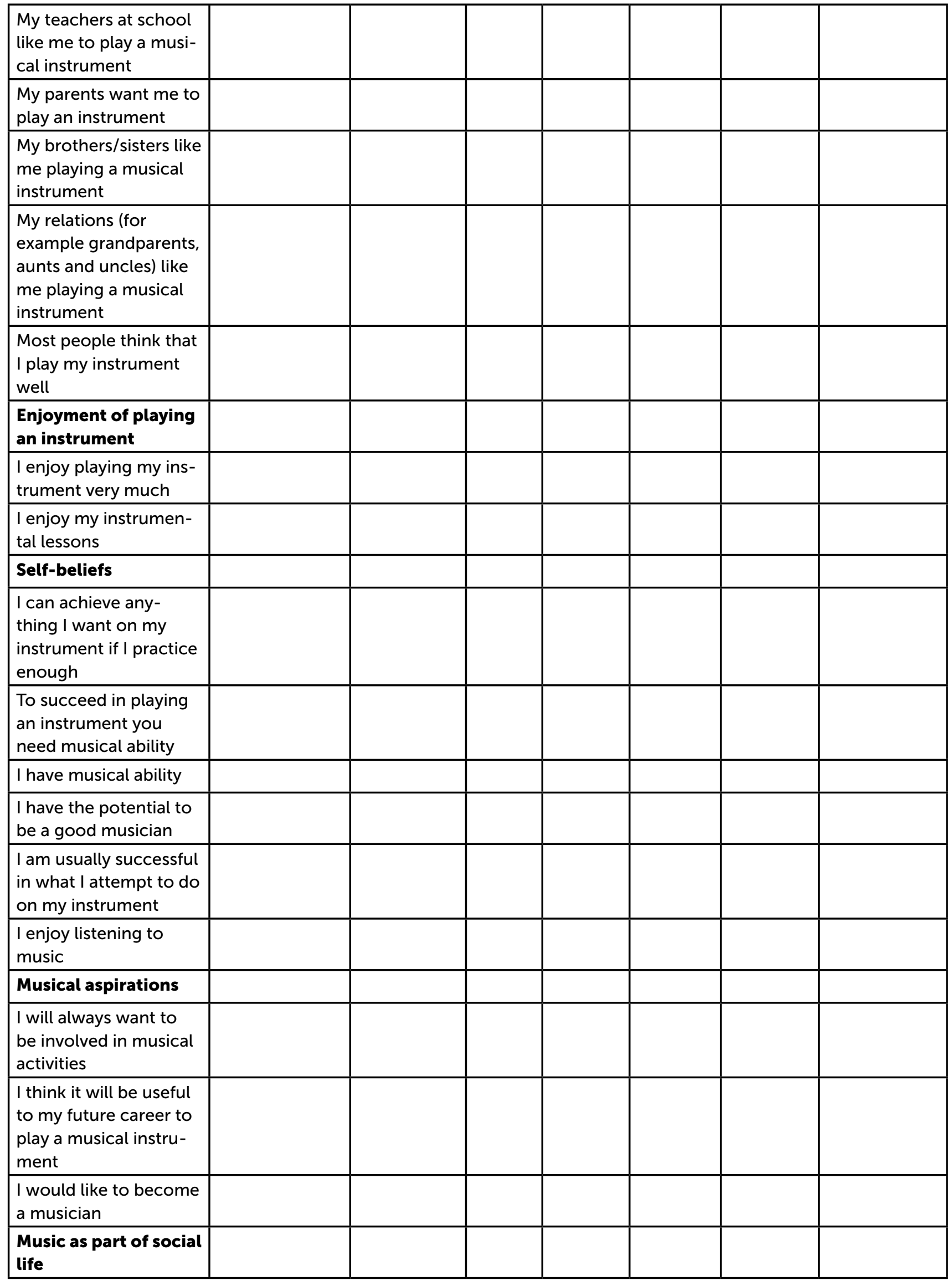




\begin{tabular}{|l|l|l|l|l|l|l|l|}
\hline $\begin{array}{l}\text { Playing an instrument } \\
\text { is an important part of } \\
\text { my social life }\end{array}$ & & & & & & & \\
\hline $\begin{array}{l}\text { I have a lot of friends } \\
\text { who play musical ins- } \\
\text { truments }\end{array}$ & & & & & & & \\
\hline $\begin{array}{l}\text { I enjoy playing in mu- } \\
\text { sical groups, orches- } \\
\text { tras and bands }\end{array}$ & & & & & & & \\
\hline $\begin{array}{l}\text { I enjoy going to con- } \\
\text { certs to listen }\end{array}$ & & & & & & & \\
\hline $\begin{array}{l}\text { Value placed on } \\
\text { music }\end{array}$ & & & & & & & \\
\hline $\begin{array}{l}\text { I think it is valuable to } \\
\text { play a musical instru- } \\
\text { ment }\end{array}$ & & & & & & & \\
\hline Performance & & & & & & & \\
\hline $\begin{array}{l}\text { I find it very satisfying } \\
\text { to play in concerts }\end{array}$ & & & & & & & \\
\hline $\begin{array}{l}\text { Playing in concerts } \\
\text { gives me a real thrill }\end{array}$ & & & & & & & \\
\hline
\end{tabular}

Thank you for completing this questionnaire. 